\title{
Domestic wastewater treatment performance using constructed wetland
}

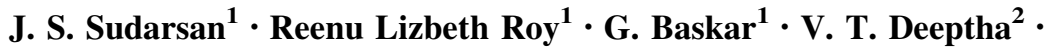 \\ S. Nithiyanantham ${ }^{3}$
}

Received: 27 March 2015 / Accepted: 22 May 2015/Published online: 3 June 2015

(C) Springer International Publishing 2015

\begin{abstract}
Constructed wetlands are treatment systems that use natural processes involving wetland vegetation, soils, and their associated microbial assemblages to improve water quality. These systems can be used commercially for efficient biological treatment of wastewater, and it will also act as a better eco-friendly method when compared with other conventional treatment methods. A constructed wetland pilot scale unit was constructed in the SRM University campus which was allowed to treat wastewater from the sewage treatment plant III. The pilot scale unit was designed based on EPA and CPCB guidelines. The dimension of the constructed wetland was $250 \times 150 \times 80 \mathrm{~cm}$ with a slope of $0.01(1 \%)$. The design is as per Darcy's law. The wetland unit has a cross section of $3.75 \mathrm{~m}^{2}$ and has been designed with hydraulic loading of $0.8 \mathrm{~m}^{3} /\left(\mathrm{m}^{2} /\right.$ day $)$ and recommended flow of $3 \mathrm{~m}^{3} /$ day. The retention time provided for the unit was 24 , 48, 72, 96, and 120 h. Phragmites australis also known as
\end{abstract}

S. Nithiyanantham

s_nithu59@rediffmail.com

J. S. Sudarsan

sudarsanjss@yahoo.com

1 Department of Civil Engineering, Faculty of Engineering and Technology, SRM University,

Kattankulathur, Kanchipuram Dt. 603 203, Tamil Nadu, India

2 Department of Civil Engineering, New Prince Shri Bhavani College of Engineering \& Technology, Vengaivasal Main Road, Gowrivakkam, Chennai 600 073, Tamil Nadu, India

3 Applied Energy Resource Divisions, School of Physical Sciences and Femtotechnology, SRM University, Kattankulathur, Kanchipuram Dt. 603 203, Tamil Nadu, India common reed was the wetland plant species planted in the unit. Six field trials were carried out during the project and with average removal efficiencies of $75.99 \%$ for BOD, $76.16 \%$ for COD, $57.34 \%$ for TDS, $62.08 \%$ for Nitrate, $58.03 \%$ for Phosphate, $57.83 \%$ for Potassium.

Keywords Constructed wetland - Wastewater treatment . Plant species $\cdot$ Microbial analysis

\section{Introduction}

As a part of outgoing research, wetlands are some of the most biologically diverse and productive natural ecosystems in the world. While not all constructed wetlands (CWs) replicate natural ones, it makes sense to construct wetlands that improve water quality and support wildlife habitat (EPA Manual 2004; Sudharsan et al. 2014). CWs can also be a cost-effective and technically feasible approach to treating wastewater. Wetlands are often less expensive to build than traditional wastewater treatment options, have low operating and maintenance expenses, and can handle fluctuating water levels. Additionally, they are esthetically pleasing and can reduce or eliminate odors associated with wastewater.

CWs are generally built on uplands and outside floodplains or floodways in order to avoid damage to natural wetlands and other aquatic resources. Wetlands are frequently constructed by excavating, backfilling, grading, diking, and installing water control structures to establish desired hydraulic flow patterns. If the site has highly permeable soils, an impervious, compacted clay liner is usually installed and the original soil placed over the liner. Wetland vegetation is then planted or allowed to establish naturally (EPA Manual 2004). 


\section{Constructed wetlands}

A constructed wetland is a shallow basin filled with some sort of filter material (substrate), usually sand or gravel, and planted with vegetation tolerant of saturated conditions. Wastewater is introduced into the basin and flows over the surface or through the substrate, and is discharged out of the basin through a structure which controls the depth of the wastewater in the wetland (CN Manual 2008).

A constructed wetland comprises the following five major components:

1. Basin,

2. Substrate,

3. Vegetation,

4. Liner, and

5. Inlet/Outlet arrangement system (CN Manual 2008).

The objectives of the project were to identify the organic loading removal efficiency of CWs. This project work attempts to put the proper perspective on appropriate use of CWs. For some applications, these are best options because they are low in cost, maintenance requirements, offer good performance, and provide a natural appearance and more ecological benefits. They are well suited for wastewater treatment in small communities where inexpensive land is available and skilled operators are hard to find. Constructed wetland systems can be used commercially for efficient biological treatment of waste water. It is a better ecofriendly method than other conventional treatment methods.

\section{Materials and methods}

Natural wetlands, marshes, swamps, and bogs play an important role in protecting water quality. Constructed or artificial wetland systems mimic the treatment that occurs in natural wetlands by relying on plants and a combination of naturally occurring biological, chemical, and physical processes to remove pollutants from the water. Because constructed wetland systems are designed specifically for wastewater treatment, they typically work more efficiently than natural wetlands. Some constructed wetland system designs can closely resemble natural wetlands enough to provide additional habitat areas for many birds, animals, and insects that thrive in wetland environments.

\section{Study area}

The wastewater for project work was taken from the Sewage treatment plant STP III located at the SRM University Campus. This work was carried out in SRM University campus and the samples were collected from sewage treatment plants III located near SRM Nagar of Potheri village $\left(12^{\circ} 9^{\prime} \mathrm{N}-12^{\circ} 49^{\prime} \mathrm{N}\right.$ and $80^{\circ} 2^{\prime} \mathrm{E}$ and $\left.80^{\circ} 3^{\prime} \mathrm{E}\right)$ in Kancheepuram District, Tamil Nadu, India. This area experienced maximum temperature of $40{ }^{\circ} \mathrm{C}$ and minimum temperature of $20^{\circ} \mathrm{C}$ and average rainfall of $1403 \mathrm{~mm}$. The University is located along $\mathrm{NH} 45$, about $40 \mathrm{~km}$ way from Chennai city.

\section{Sample collection points}

Wastewater sampling was performed by one of the two methods, grab sampling, and composite sampling. Composite sampling was the type of sampling that has been used in the collection of wastewater. Composite sampling consists of a collection of numerous individual discrete samples taken at regular intervals over a period of time, usually $24 \mathrm{~h}$. The wastewater samples were taken using a gouge from a depth of $10 \mathrm{~cm}$. The samples were stored in polyethylene plastic bottles, transported to the laboratory on the same day, and stored in the dark at $4{ }^{\circ} \mathrm{C}$ until making the experimental procedure (Cavusoglu et al. 2010).

\section{Wetland site}

The experimental pilot scale unit was located near the sewage treatment plant III at the SRM University, Kattankulathur Campus. The domestic wastewater was collected and pumped from the pre-aeration tank of sewage treatment plant in the university and was discharged into the wetland unit.

\section{Wastewater sampling and analysis}

The sewage to be treated and reused in the campus was subjected to characteristic study. The following parameters were determined based on standard methods (APHA 1998): $\mathrm{pH}$, specific conductivity (SC), biochemical oxygen demand (BOD), chemical oxygen demand (COD), total dissolved solids (TDS), nitrate, phosphate, and potassium.

The analysis was done immediately after sample collection, otherwise were properly stored. Waste water samples were taken using a gouge from the depth $10 \mathrm{~cm}$. The samples were stored in polyethylene plastic bottles, transported to the laboratory on the same day, and stored in the dark at $4{ }^{\circ} \mathrm{C}$ until making the experimental procedure (Cavusoglu et al. 2010).

\section{Constructed wetland unit}

The pilot scale model was designed based on the design manuals of EPA and CPCB. The dimension of the constructed wetland was $250 \times 150 \times 80 \mathrm{~cm}$ with a slope of $0.01(1 \%)$. 
The design is as per Darcy's law. The wetland model of cross section $3.75 \mathrm{~m}^{2}$ has been designed with hydraulic loading of $0.8 \mathrm{~m}^{3} /\left(\mathrm{m}^{2} /\right.$ day $)$ and recommended flow of $3 \mathrm{~m}^{3} /$ day. The retention time provided was $24,48,72,96$, and $120 \mathrm{~h}$.

The wetland media consisted of a gravel bed underlain on an impermeable concrete surface. The bed was filled to a height of $50 \mathrm{~cm}$ with coarse rock, medium gravel, fine gravel, gravelly sand, and coarse sand. The top portion of the wetland unit was filled with local sandy clay loam soil to support vegetation. This process depicted in Fig. 1.

\section{Plant material}

Phragmites australis also known as common reed was used in this study. The plants were collected from a nearby lake and planted in the wetland unit 3 months before the commencement of treatment. The vegetation was planted by hand and normal water was used to grow plants. These plants increase the residence time of water by reducing velocity and increase sedimentation of the suspended particles. They also add oxygen and provide a physical site for microbial bioremediation. The plants have been used to remove suspended solids, nutrients, heavy metals, toxic organic compounds, and bacteria (Deepak et al. 2012).

\section{Maintenance}

The system was inspected on a weekly basis concerning the overall functioning. Major attention was given to the inlet flow, which was checked twice a week, as clogging may occur due to the presence of suspended solids.

\section{Results and discussion}

The raw wastewater in the treatment plant mainly comes from hostels, canteens, bathrooms, washing areas, laundry services in the campus. The wastewater after treatment is mainly used for gardening and rest of the water is sent to the lakes in the premises.

The Domestic wastewater from The pre-aeration tank of SRM Sewage treatment plant III was sent to the constructed wetland unit which was constructed near the treatment plant. The domestic wastewater was pumped using a pump at a rate of 7 1/s. After treatment, the wastewater i.e., after providing a detention period of 5 days the water, was analyzed for various parameters like $\mathrm{pH}, \mathrm{SC}$, dissolved oxygen (DO), BOD, COD, TDS, nitrate, phosphate, and potassium. The pilot scale unit created was a concrete tank of capacity $3 \mathrm{~m}^{3}$ with soil and vegetation in it. The vegetation planted was Phragmites australis (common reed). A total of six trials were carried out with a detention time of 5 days. The reduction in concentration of various parameters during 1-5 day period was compared and analyzed. The reduction pattern in each of the trials is obtained.

Data representation and statistical analysis was done using error graphs and $t$ test.

\section{Field trial I}

The subsurface integrated flow constructed wetland was constructed and proper setting of the unit was done. The commencement of functioning of the pilot scale unit began on January 2014.

Figure $2 \mathrm{a}, \mathrm{b}$ shows the reduction in concentration of various parameters with respect to time. As the detention time increases, the reduction percentage is also increased, a detention period of 5 days is given for the constructed wetland. The removal efficiencies of various parameters after 5th day were $63.16 \%$ for BOD, $62.96 \%$ for COD, $52.63 \%$ for TDS, $64.29 \%$ for Nitrate, $46.60 \%$ for Phosphate, $44.27 \%$ for Potassium.

\section{Field trial II}

Figure $3 \mathrm{a}, \mathrm{b}$ shows the reduction in concentration of various parameters with respect to time. As the detention time increases the reduction percentage is also increased; a detention period of 5 days is given for the constructed wetland. The various removal efficiencies were $60 \%$ for BOD, $60.48 \%$ for COD, $60 \%$ for TDS, $60.53 \%$ for Nitrate, $53.27 \%$ for Phosphate, and $50 \%$ for Potassium.

\section{Field trial III}

Figure $4 a, b$ shows the reduction in concentration of various parameters with respect to time. As the detention time increases the reduction percentage is also increased; a detention period of 5 days is given for the constructed wetland. The reduction percentages obtained for various

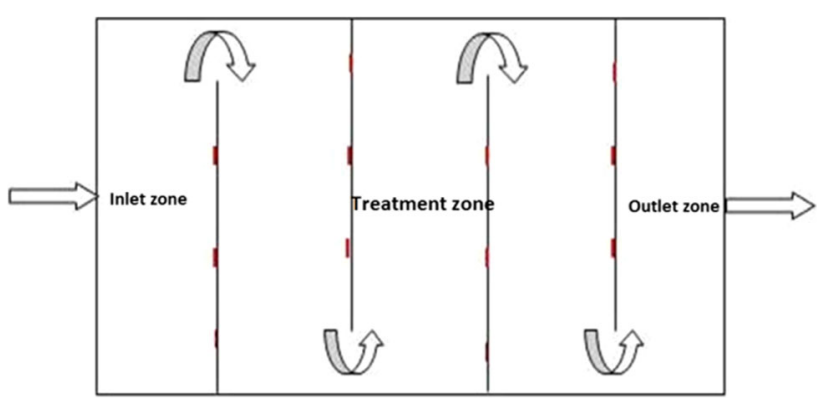

Fig. 1 Experimental setup (Top view) 
(a)

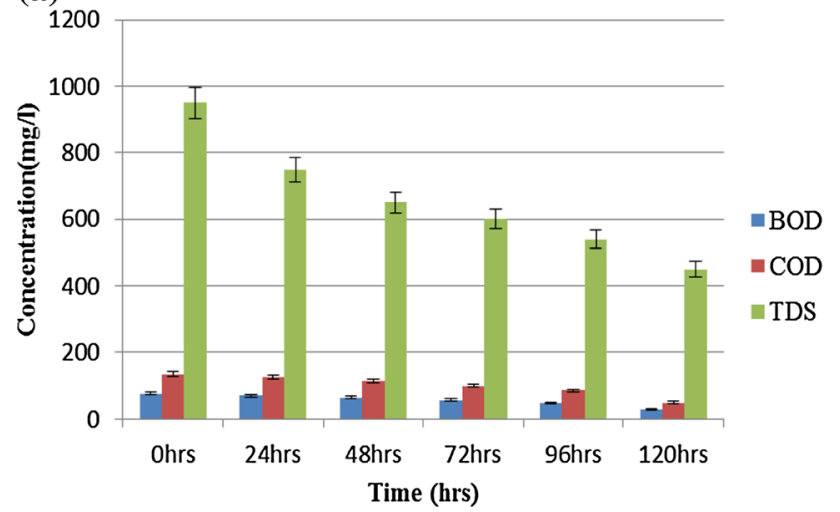

(b)

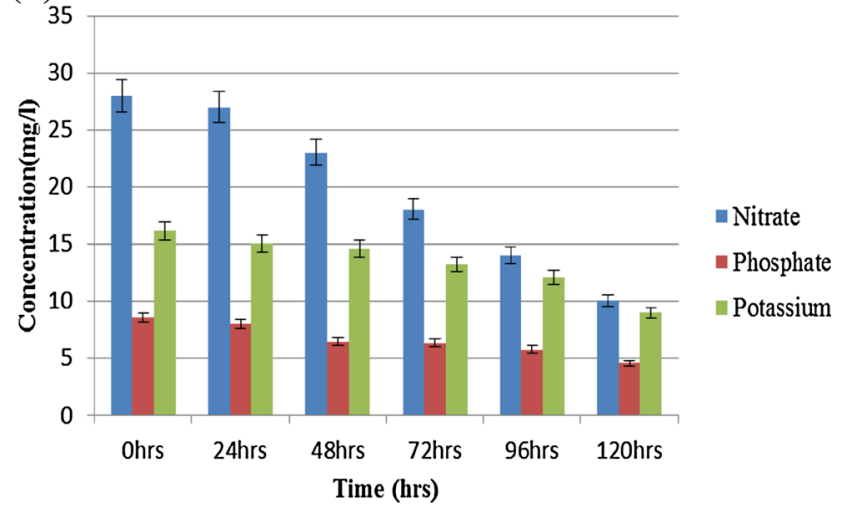

Fig. 2 Reduction in concentration from influent and effluent of waste water. a BOD, COD and TDS, b Nitrate, phosphate, and potassium

(a)

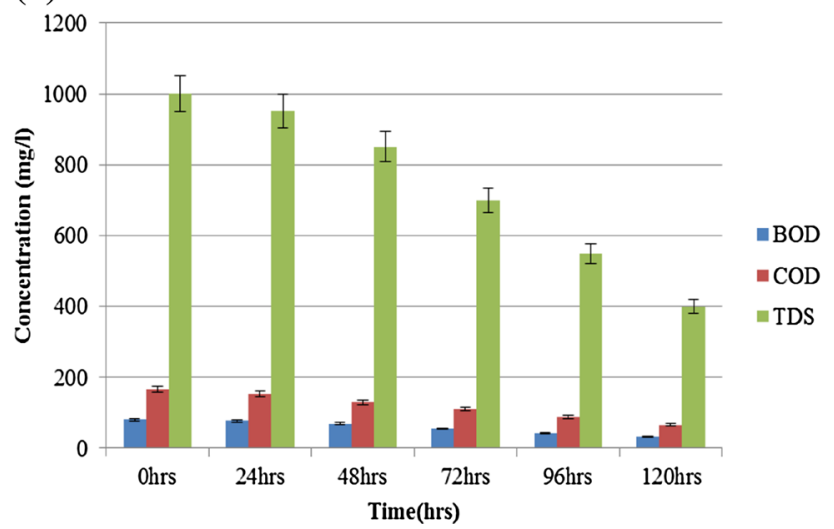

(b)

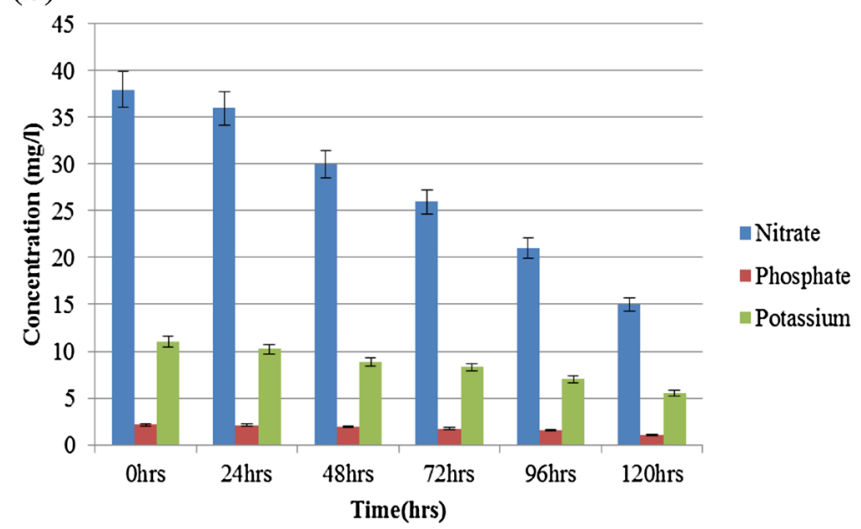

Fig. 3 Reduction in concentration from influent and effluent of waste water. a BOD, COD, and TDS, b Nitrate, phosphate, and potassium

parameters were $82.61 \%$ for BOD, 82.69 for COD, $57.89 \%$ for TDS, $62.86 \%$ for Nitrate, $47.37 \%$ for Phosphate, and $73.33 \%$ for Potassium.

\section{Field trial IV}

Figure $5 \mathrm{a}, \mathrm{b}$ shows the reduction in concentration of various parameters with respect to time. As the detention time increases the reduction percentage is also increased; a detention period of 5 days is given for the constructed wetland. The reduction percentages obtained were $79.49 \%$ for BOD, $81.45 \%$ for COD, $59.17 \%$ for TDS, $65.22 \%$ for Nitrate, $74.82 \%$ for Phosphate, and $64.17 \%$ for Potassium.

\section{Field trial V}

Figure $6 a, b$ shows the reduction in concentration of various parameters with respect to time. As the detention time increases the reduction percentage is also increased; a detention period of 5 days is given for the constructed wetland. The various removal efficiencies observed during trial V were $84.44 \%$ for BOD, $84.92 \%$ for COD, $58.33 \%$ for TDS, $58.06 \%$ for Nitrate, $63.77 \%$ for Phosphate, and $52.73 \%$ for Potassium.

\section{Field trial VI}

Figure $7 \mathrm{a}, \mathrm{b}$ shows the reduction in concentration of various parameters with respect to time. As the detention time increases the reduction percentage is also increased; a detention period of 5 days is given for the constructed wetland. The various reduction efficiencies observed were $86.22 \%$ for BOD, $84.44 \%$ for COD, $56 \%$ for TDS, $61.54 \%$ for Nitrate, $62.32 \%$ for Phosphate, and $62.5 \%$ for Potassium. The various forms of nitrogen are continually involved in chemical transformations from inorganic to organic compounds and back from organic to inorganic. Some of these processes require energy (typically derived from an organic carbon source) to 
(a)

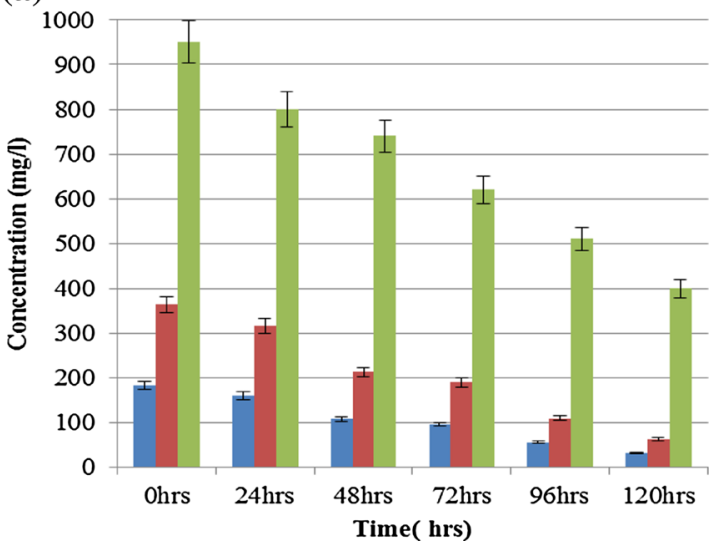

(b)

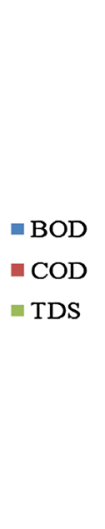

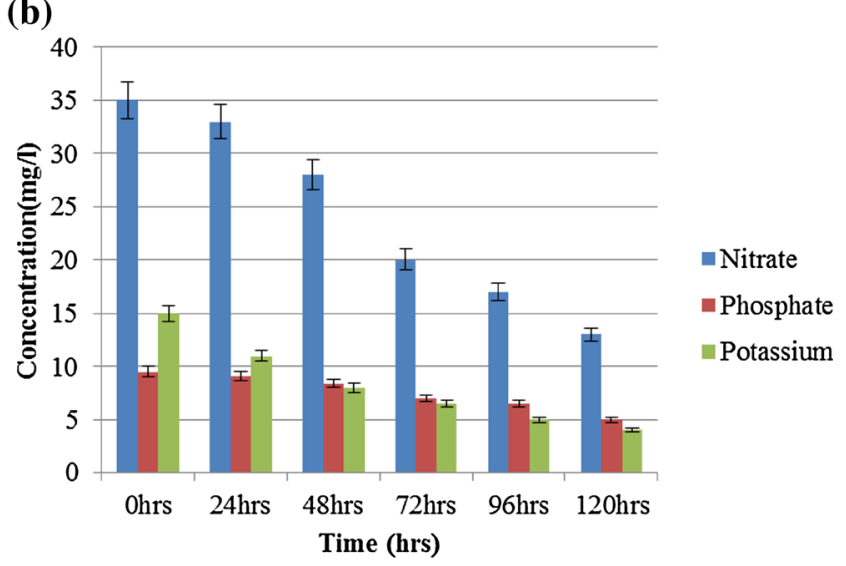

Fig. 4 Reduction in concentration from influent and effluent of waste water. a BOD, COD, and TDS, b Nitrate, phosphate, and potassium

(a)

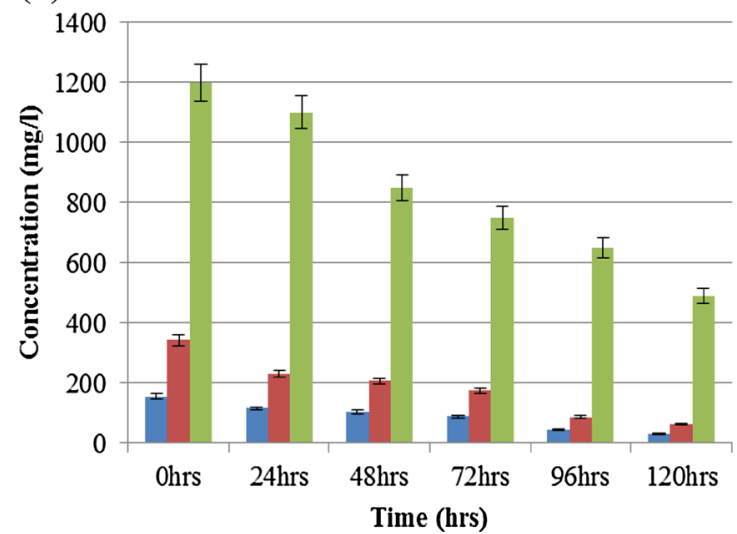

(b)

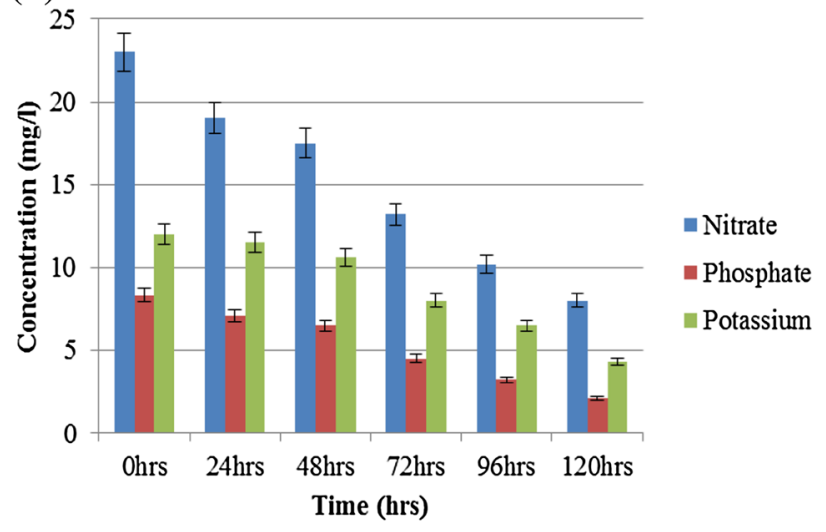

Fig. 5 Removal of concentration from influent and effluent of waste water. a BOD, COD, and TDS, b Nitrate, phosphate, and potassium

(a)

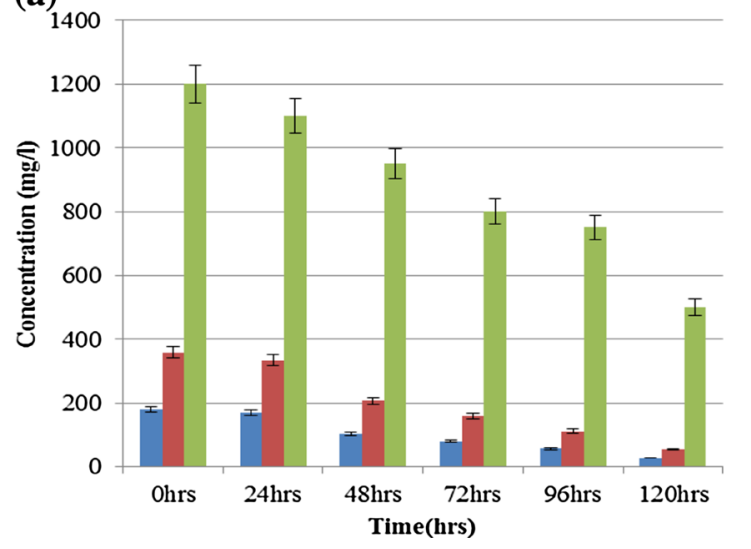

(b)

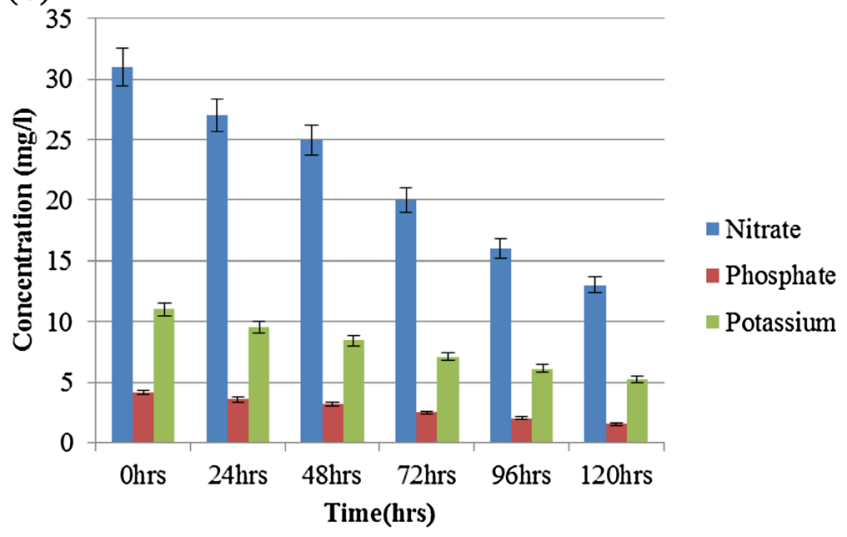

Fig. 6 Reduction of concentrations from waste water. a BOD, COD, and TDS, b Nitrate, phosphate, and potassium

proceed, and others release energy, which is used by organisms for growth and survival. All of these transformations are necessary for wetland ecosystems to function successfully, and most chemical changes are controlled through the production of enzymes and catalysts by the living organisms they benefit (Vymazal and Krasa 2003).

The overall wetland system performance is expected to be high and stable for this type of wastewater during the 
(a)

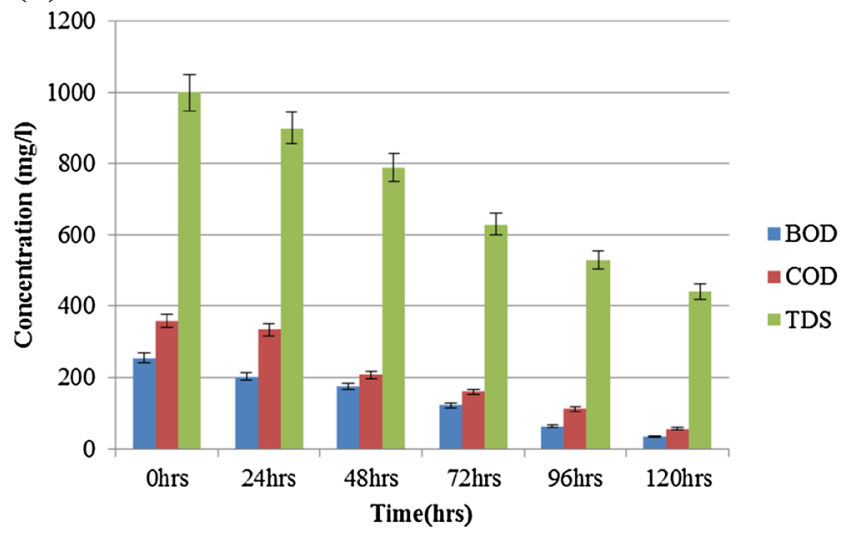

(b)

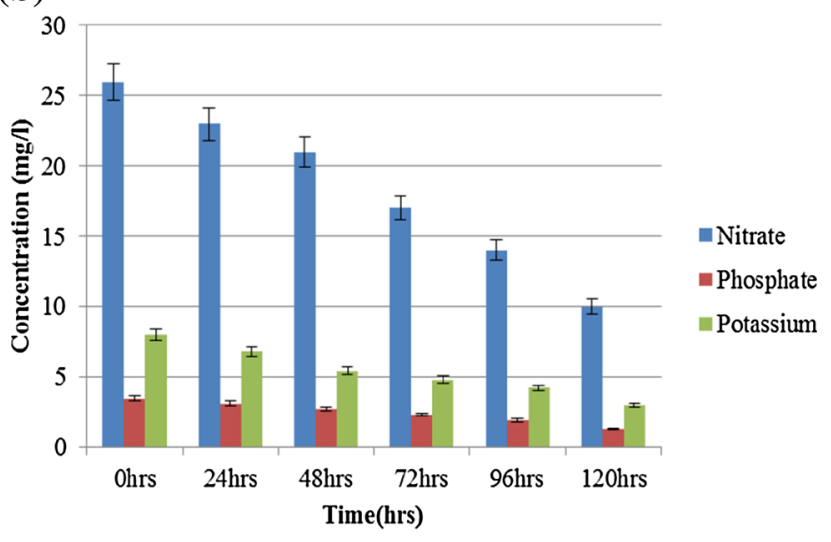

Fig. 7 Reduction of concentrations from waste water. a BOD, COD, and TDS, b Nitrate, phosphate, and potassium

forthcoming observation period. Implementing this wastewater treatment system in SRM university campus can create awareness on environmental consciousness to the students, staff, and other residents of the township. Statistical analysis of concentration reductions in the domestic wastewater treatment using $\mathrm{CWs}$ was compared using $t$ test.

\section{Statistical analysis using $t$ test}

A $t$ test compares the means of two groups. For example, we compare whether systolic blood pressure differs between a control and treated group, between men and women, or any other two groups. Here, we have compared the means of different parameters like BOD, COD, TDS, Nitrate, Phosphate, and Potassium before and after treatment. The processes that affect removal and retention of nitrogen during wastewater treatment in CWs are manifold and include $\mathrm{NH}_{3}$ volatilization, nitrification, denitrification, nitrogen fixation, plant and microbial uptake, mineralization (ammonification), nitrate reduction to ammonium (nitrate-ammonification), anaerobic ammonia oxidation (ANAMMOX), fragmentation, sorption, desorption, burial, and leaching. However, only few processes ultimately remove total nitrogen from the wastewater while most processes just convert nitrogen to its various forms (Vymazal 2007).

The unpaired $t$ test compares the means of two groups. The most useful result is the confidence interval for the difference between the means. If the assumptions of the analysis are true, we can be $95 \%$ sure that the $95 \%$ confidence interval contains the true difference between the means. The point of the experiment was to see how far apart the two means are. The confidence interval tells us how precisely we know that difference. For many purposes, this confidence interval is all you need.
The $P$ value was used to ask whether the difference between the mean of two groups is likely to be due to chance. It is traditional, but not necessary and often not useful, to use the $P$ value to make a simple statement about whether or not the difference is "statistically significant." We will interpret the results differently depending on whether the $P$ value is small or large.

Table 1 shows the BOD, COD, Total dissolved solids, Nitrate, Phosphate, and Potassium value comparison of raw and treated wastewater analysis using $t$ test. The table shows comparison of mean, Standard deviation, Standard error mean. The two-tailed $P$ value equals 0.0029 . By conventional criteria, this difference is considered to be very statistically significant. The mean of raw water minus treated water equals $124.60 .95 \%$ confidence interval is obtained with difference from 55.12 to 194.08. Intermediate values used in calculations were $t=4.0569, \mathrm{df}=9$, and standard error of difference $=30.713$.

The two-tailed $P$ value for COD comparison equals 0.0011 . By conventional criteria, this difference is considered to be very statistically significant. The mean of raw water minus treated water equals 228.280. $95 \%$ confidence interval of this difference: From 119.345 to 337.215 intermediate values used in calculations are $t=4.7405$, $\mathrm{df}=9, \quad$ and standard error of difference $=48.156$ (Table 2).

The two-tailed $P$ value for TDS is less than 0.0001 . By conventional criteria, this difference is considered to be extremely statistically significant. The mean of raw water minus treated water equals 603.33 . $95 \%$ confidence interval of this difference is from 488.90 to 717.77 . Intermediate values used in calculations are $t=11.7473$, $\mathrm{df}=10$, and standard error of difference $=51.359$.

The two-tailed $P$ value for nitrate equals 0.0003 . By conventional criteria, this difference is considered to be extremely statistically significant. The mean of raw water minus treated water equals $16.17 .95 \%$ confidence interval 
Table 1 BOD, COD, and TDS value comparison using $t$ test

\begin{tabular}{|c|c|c|c|c|c|c|c|}
\hline \multirow[t]{2}{*}{ Sl. no. } & \multirow[t]{2}{*}{ Group } & \multicolumn{2}{|l|}{ BOD } & \multicolumn{2}{|l|}{ COD } & \multicolumn{2}{|l|}{ TDS } \\
\hline & & Raw & Treated & Raw & Treated & Raw & Treated \\
\hline 1 & Mean & 155.00 & 30.40 & 287.600 & 59.320 & 1050.00 & 446.67 \\
\hline 2 & SD & 68.02 & 2.19 & 106.516 & 6.922 & 118.32 & 42.74 \\
\hline 3 & SEM & 27.77 & 0.98 & 43.485 & 3.096 & 48.30 & 17.45 \\
\hline 4 & $N$ & 6 & 5 & 6 & 5 & 6 & 6 \\
\hline
\end{tabular}

Table 2 Nitrate, phosphate, and potassium value comparison using $t$ test

\begin{tabular}{|c|c|c|c|c|c|c|c|}
\hline \multirow[t]{2}{*}{ Sl. no. } & \multirow[t]{2}{*}{ Group } & \multicolumn{2}{|c|}{ Nitrate } & \multicolumn{2}{|c|}{ Phosphate } & \multicolumn{2}{|c|}{ Potassium } \\
\hline & & Raw & Treated & Raw & Treated & Raw & Treated \\
\hline 1 & Mean & 30.17 & 14.00 & 6.0183 & 2.8320 & 12.1917 & 5.6000 \\
\hline 2 & SD & 5.64 & 3.32 & 3.1317 & 1.8271 & 2.9665 & 1.9987 \\
\hline 3 & SEM & 2.30 & 1.48 & 1.2785 & 0.8171 & 1.2111 & 0.8939 \\
\hline 4 & $N$ & 6 & 5 & 6 & 5 & 6 & 5 \\
\hline
\end{tabular}

is obtained with a difference from 9.66 to 22.67 . Intermediate values used in calculations are $t=5.6239, \mathrm{df}=9$, and standard error of difference $=2.875$.

The two-tailed $P$ value for phosphate equals 0.0767 . By conventional criteria, this difference is considered to be not quite statistically significant. The mean of raw water minus treated water equals $3.1863 .95 \%$ confidence interval is obtained of difference from -0.4202 to 6.7929 . Intermediate values used in calculations are $t=1.9986, \mathrm{df}=9$, and standard error of difference $=1.594$.

The two-tailed $P$ value for Potassium equals 0.0023 . By conventional criteria, this difference is considered to be very statistically significant. The mean of raw water minus treated water equals $6.5917 .95 \%$ confidence interval of difference from 3.0554 to 10.1280 is obtained. Intermediate values used in calculations: $t=4.2167, \mathrm{df}=9$, and standard error of difference $=1.563$.

After $t$ test analysis, it was observed that every parameter before and after treatment is showing a $95 \%$ confidence interval which means the constructed wetland is showing higher removal efficiency for all the selected parameters. Nitrification and denitrification are the main processes for nitrogen removal from wastewater. Denitrification is an anaerobic heterotrophic microbial process often limited by the presence of oxygen $\left(\mathrm{O}_{2}\right)$ and the availability of labile carbon substrates. Nitrification is an aerobic chemoautotrophic process (Ong et al. 2011). The major processes responsible for phosphorus removal in SFWC are typically by adsorption, precipitation, and plant up-take rates. The frequent filtration materials used in SFCW are gravel, which is commonly good in absorption compared to the plant roots (Vymazal 2004). Phosphorus is an important nutrient required for plant growth and is usually act as a limiting factor for vegetative productivity. Phosphorus is transformed in the wetland by a complicated biogeochemical cycle. Accordingly, most of the researchers claimed that wetlands are not efficient in phosphorus reduction (Kadlec and Knight 1996; Adeniran et al. 2012; Akratos et al. 2008).

\section{Conclusion}

The treatment of domestic wastewater from sewage treatment plant III in integrated sub-surface flow constructed wetland vegetated with Phragmites australis is working well in degradation of high concentration of wastes. The average removal efficiencies obtained for the respective constructed wetland were $75.99 \%$ for BOD, $76.16 \%$ for COD, $57.34 \%$ for TDS, $62.08 \%$ for Nitrate, $58.03 \%$ for Phosphate, and $57.83 \%$ for Potassium, and thus the organic loading removal efficiency of the $\mathrm{CW}$ unit was identified.

The wastewater treatment system on the SRM university campus using CWs has created awareness on environmental consciousness to the students, staff, and other residents of the township. The treated effluent values obtained were convenient with current Central Pollution Control Board regulations for domestic wastewater discharge. Implementing the constructed wetland technology is suitable for decentralized domestic wastewater treatment. The Integrated surface flow constructed wetland system by using Phragmites australis seems to be viable alternative for reducing the organic matter content from an institutional complex. CWs act like primarily biological filters and are very effective in removing BOD, COD, TSS, and organic nitrogen. When comparing performance of wetlands, the comparison should be based on the performance of complete systems remembering that wetlands are only one part of a multi-part system. 
Acknowledgments The authors thank gratefully to the management, SRM University, and the HOD Civil Engineering Department for their support and encouragement in executing the project in successful manner.

\section{References}

Adeniran AE, Aina AT, Oshunrinade OO, Oyelowo MA (2012) Assessment of the efficiency of constructed wetland in domestic wastewater treatment at the university of Lagos, Nigeria. J Sustain Dev Environ Prot 2:252-256

Akratos CS, Papaspyros JNE, Tsihrintzis VA (2008) Artificial neural network use in ortho-phosphate and total phosphorus removal prediction in horizontal subsurface flow constructed wetlands. Bio Syst Eng 100:1-12

Cavusoglu K, Yapar K, Kinalioglu K, Turkmen Z, Cavusoglu K, Yalcin E (2010) Protective role of Ginkgo biloba on petroleum wastewater-induced toxicity in Viciafaba L. (Fabaceae) root tip cells. J Environ Biol 31:319-324

EPA Manual (2004) Guidelines for water reuse, EPA/625/R-04/108. Accessed Sept 2004
Deepak M, Sudarasan JS, Deeptha VT, Baskar G (2012) Low cost dairy wastewater treatment using constructed wetland. J Inst Public Health Eng 3:55-60

Kadlec RH, Knight RL (1996) Treatment wetlands. Lewis Publishers, London

Ong SA, Ho LN, Wong YS, Danny LG, Hafizah S (2011) Semi-batch operated constructed wetlands planted with Phragmites australis for treatment of dyeing wastewater. J Eng Sci Technol 6:619-627

Sudarsan J, Prasanna K, Ranganathan K, Nithiyanatham S (2014) Comparative study of electricity production and treatment of different waste water using microbial fuel cell (MFC). Environ Earth Sci 73(5):2409-2413

United Nations Human settlement programme' constructed wetlands manual (2008)

Vymazal J (2004) Removal of phosphorus in constructed wetlands with horizontal subsurface flow in the Czech Republic. Water Air Soil Pollut 4:657-670

Vymazal J (2007) Removal of nutrients in various types of constructed wetlands. Sci Total Environ 380:48-65

Vymazal J, Krasa P (2003) Distribution of Mn, Al, Cu and Zn in a constructed wetland receiving municipal sewage. Wat Sci Tech 48(5):299-305 